\title{
Minimum Service Standards for Basic Education in Border Region
}

\author{
Samion $^{1}$ and Yudi Darma ${ }^{2}$ \\ ${ }^{1)}$ IKIP PGRI Pontianak, Pontianak, Indonesia \\ E-mail: samion14@gmail.com \\ 2) IKIP PGRI Pontianak, Pontianak, Indonesia \\ E-mail: yudidarmamtk@gmail.com
}

\begin{abstract}
This study aims to analyze the achievement of MSS Basic Education, with a case study in the border area Entikong District of the district, followed by alternatives for achieving the standards in 2017 and prepare a strategy for its achievement. The method used in the study is the evaluation of research with the evaluation model inaccuracies or gaps (The Discrepancy Evaluation Model). This research subject is the Education Unit at the District Cabdikpora environment Entikong Sanggau consisting of principals and teachers, and Head Cabdikpora. The data used are primary and secondary data. The findings of these studies it is known that the availability of educational unit within an affordable than permanent settlement group; the number of students in each group learning for SD/MI does not exceed 32 people, while SMP/MTs exceeding 36, not available 1 (one) classrooms and there are not furnished with a table and chairs; each SMP/MTs provided a laboratory space science; Each Primary School/not available 1 (one) class teachers for each study group and for SMP/MTs unavailable teacher of Religious Education, Indonesian, Social Sciences, Arts, PE, and ICT; each SD/MI and SMP/MTs provided two (2) teachers who meet the academic qualifications S1 as much as 70\%, but does not have a teaching certificate for the SD/MI; Chief of SD/MI has not qualified academic S-1 or D-IV and have a teaching certificate, already for SMP/MTs; curriculum development and innovative learning process is not implemented effectively; 50\% SD/MI which has 100 titles enrichment and 10 reference books and each SMP/MTs 200 items of enrichment books and 20 reference books; $58.33 \%$ of permanent teachers work 35 hours per week in the education unit; $66.66 \%$ educational unit organized a learning process for 34 weeks per year; $66.66 \%$ The principal supervising lessons and provide feedback to teachers twice each semester.
\end{abstract}

Keywords: Minimum Service Standards; The Border Area

\section{INTRODUCTION}

Basic education is a basic foundation in the form of human/next generation quality. This is in accordance with the demands of the subjects that can deliver the required competence in children at a very age (infancy). Not a few children who live without basic education through Early Childhood Education (ECD) and/or Kindergarten (TK) which also greatly affects its readiness to continue at the level of primary school.

No wonder if the optimization of various lines made by the government, the school, and the community (parents) to improve the quality of students in basic education. Because, basic education can be likened to building a house of cards, if the bottom card vacillate position, it will cause the collapse of the entire building.

Real form of government is done in optimizing the sustainable level of basic education continues diupaykan, ranging from the improvement of facilities for pre facilities, curriculum development, improve the welfare of teachers, and there are many programs that are designed to improve the quality of education. It is also done by the parents, ranging from providing facilities, child nutrition, to provide additional tutoring outside of school (tutoring), both privately and classical.

In this regard the efforts made can be seen the extent to which the value or the evaluation results obtained. Images of accreditation the school / madrasah's West Kalimantan province itself still needs special perhataian. Of the 32 
provinces in 2013, the position of West Kalimantan in below average, even some of the standard 8 standard targeted accreditation ratings are at the two lowest numbers nationwide.

Based on these data with respect to the quality of course not independent of management and the management of quality school. Because quality school is a portrait of a quality education. So that the activities of implementation of management education in primary school is to achieve minimum service standards must be optimally so as to provide useful contribution towards improving the quality of basic education.

Understanding the importance of national education, the government continues to strive for the fulfillment of the right of every citizen in obtaining educational services to improve the quality of life of the nation. As the Preamble to the Constitution of the Republic of Indonesia in 1945 that obliges the government responsible for educating the nation and create common prosperity.

The government has made various efforts to improve public education Indonesia, one of them through a Compulsory Basic Education program 9 Year contained in Candy No. 47 of 2008. Compulsory Basic Education 9 Year consists of SD and MI or other levels equal to at least junior high school and MTs or other equivalent level.

Minimum Service Standards is one of the government's efforts in improving the quality of Compulsory Basic Education 9 Year evenly. Minimum Service Standards is a measure of the performance of educational services held areas. Provincial Government and District/Municipal education by SPM in accordance with the Decree of the Minister of Education No. 129a/U/2004 About Minimum Service Standards Education is continuously updated until the Permendikbud Number 23 Year 2013 on the Amendment of National Education Minister Regulation No. 15 Year 2010 About the Service Standards minimal Basic Education in the District / City.

In accordance with the demands in the fulfillment of the MSS announced by the government would also need to be a top priority of the government, schools and the community so that a minimum service level in every school meets the standard criteria that have been determined. Subdistrict Entikong Sanggau is one area which is also a top priority. Because the District Entikong a border region which is a leading window between neighboring countries, in particular the country of Malaysia.

Aside from being a border area, another reason that attracted the attention of researchers in selecting the District Entikong Sanggau as the target area of research is the state of education, both the means of pre-means, the results of the evaluation of education, of delay information and transport as well as one of the regions that have not carried out evaluation related to minimum service standards.

From some of the above, this study was done to see and evaluate the extent-which the implementation of minimum service standards is performed as a distribution of education as well as a vehicle for information to help the government in improving the quality of education in every aspect of that practice Minimum Service Standards which is expected to be realized as expected by the government, schools and communities. Besides that SPM is not the final goal, but rather is a step towards achieving the National Education Standards.

\section{Methodology}

This study included evaluation research. According Arikunto (2010: 36-37) evaluation is a gathering activity data or information to be compared with the criteria after it is concluded. Evaluation of the program used in the study evaluating the implementation of minimum service standards this is an evaluation model inaccuracies or gaps (The Discrepancy Evaluation Model) for this study will be to compare the implementation of the SPM with the criteria or indicators according to the Regulation of the Minister of Education and Culture No. 23 Year 2013 on Amendment Regulation National Education No. 15 Year 2010 Minimum Service Standards for Basic Education in the District / City.

This study uses a quantitative approach which is used to measure the achievement of MSS Basic Education in Elementary District of Entikong Sanggau. The method used is descriptive method. According to Azwar (2005: 7), descriptive research aims to describe the systematic and accurate facts and characteristics of the population or a particular field. Analysis of primary and secondary data as the completeness of the survey in this research study.

Subjects in this study is a source of obtaining data and research information. The subject is the source of this research is the parties who are in elementary school in the District Cabdikpora environment Entikong Sanggau consisting of principals and teachers. Place of execution of this study is programmed incidental in District Entikong Sanggau categorized as a border area where each school as a place of research subjects are domiciled (teacher teach) consisting of schools below:

Table I

Data Educational Research Sites

\begin{tabular}{ccc}
\hline No. & School & Village \\
\hline 1 & SDN No.01 & Semanget \\
\hline 2 & SDN No.02 & Panga \\
\hline 3 & SDN No.03 & Sontas \\
\hline 4 & SDN No.04 & Punti Tapau \\
\hline 5 & SDN No.05 & Suruh Tembawang \\
\hline 6 & SDN No.06 & Merau \\
\hline 7 & SDN No.07 & Mangkau \\
\hline 8 & SDN No.08 & Nekan \\
\hline 9 & SDN No.09 & Serangkang \\
\hline 10 & SDN No.10 & Pool \\
\hline 11 & SDN No.11 & Sekajang \\
\hline 12 & SDN No.12 & Entikong \\
\hline & SDN No.13 & Punti Kayan \\
\hline
\end{tabular}




\begin{tabular}{ccc}
\hline 14 & SDN No.14 & Badat \\
\hline 15 & SDN No.15 & Senutul \\
\hline 16 & SDN No.16 & Gun Jemak \\
\hline 17 & SDN No.17 & Pala Pasang \\
\hline 18 & MIS Istiqamah & Entikong \\
\hline 19 & SMPN 1 & Semanget \\
\hline 20 & SMPN 2 & Suruh Tembawang \\
\hline 21 & SMPN 3 & Sontas \\
\hline 22 & SMPN 4 & Serangkang \\
\hline 23 & SMKN 1 & Entikong \\
\hline 24 & SMK YLBE & Entikong \\
\hline
\end{tabular}

Please note that the Minimum Service Standards is not an end in education, but is part of the process required for the achievement of national education standards. Besides that, minimum service standards are the basis of the minimum standard of a school quality assessment (accreditation). Therefore, a strong and positive relationship between SPM Accreditation School/Madrasah is not only deserves to be known, but also must be met.

Application of SPM intended to ensure access and quality for people to obtain basic services of Regency/City Government in accordance with the criteria set by the Government. SPM Basic Education prepared with the following principles:

a. Applied to the obligatory functions. Therefore, the SPM is an integral part of the educational development of sustainable, comprehensive, integrated according to the National Medium Term Development Plan;

Data collection methods used in this research is the study adalaha documentary and direct communication (interview). The data collected was analyzed by descriptive quantitative and percentage of central tendency in accordance with the purpose of research which is then described according to the needs of evaluations conducted as a vehicle for the conclusion of the study.

This research instrument contain indicators of achievement (IP) SPM implementation of Basic Education is used as a guideline when making the observation, documentation and interview by comparing SPM contained in observation sheets, documentation and interviews with SPM implementation of Basic Education. Grating instrument indicators of achievement (IP) SPM Basic Education with reference to 27 Achievement Indicators adapted from Permendiknas 23 Year 2013, which is illustrated as follows:

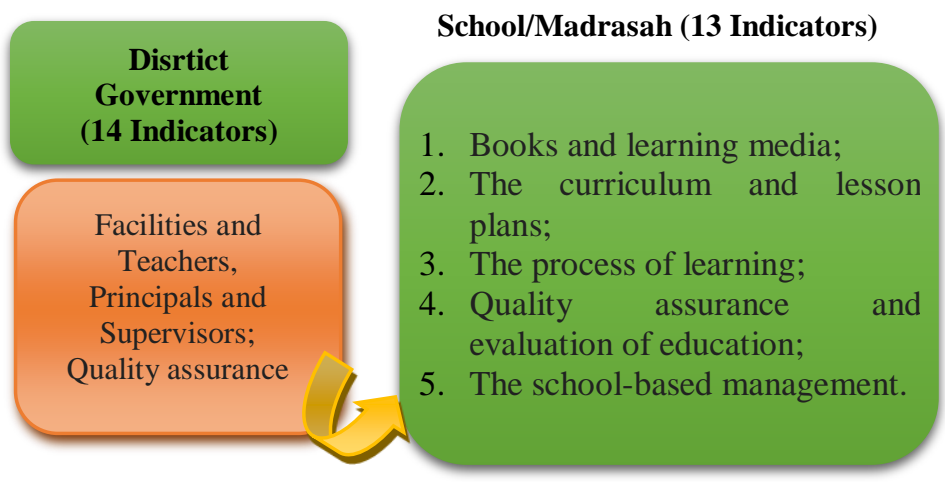

Figure 1. Minimum Service Standards Indicators

\section{RESULTS AND DISCUSSION}

The previous section described the status of the SPM under the authority level of education offices and education units. According to the division of authority in Permendiknas 15 In 2010 there is authority for the District/Municipal and authority to level Education Unit. For SPM authority of district/city level there are 14 indicators of achievement, while for the unit level of education there are 13 indicators of achievement. 


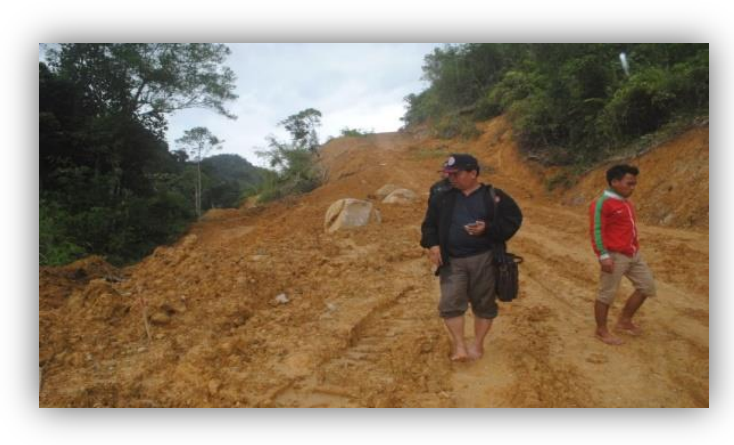

Fig. 2 Strip Land Transport (Suruh Tembawang)

In the aspect of learning romobongan (IP-2) provided information that:

a. The number of students in each group learning for SD/MI does not exceed 32; while

b. The number of students in each group learning for SMP/MTs exceed 36 people.

c. Each learning group SD/MI and SMP/MTs not available 1 (one) classroom.

d. While the SD/MI and SMP/MTS in a decent state, but every classroom SD/MI and SMP/MTS is not equipped with enough tables and chairs for students and teachers, as well as the board.

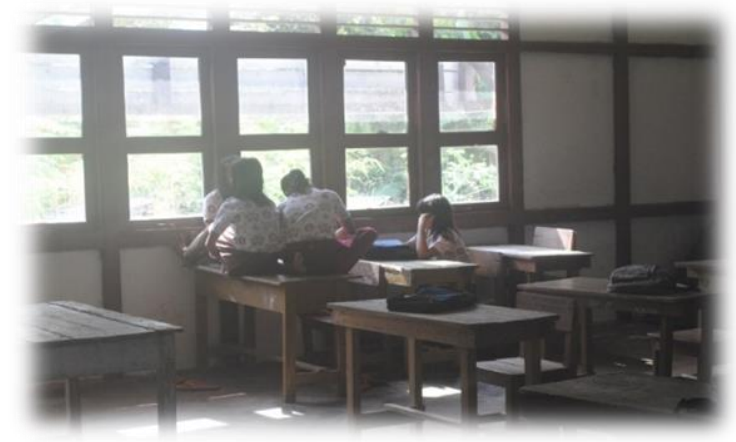

Fig. 3 The condition of classrooms

Further to the science lab space (IP-3) each SMP/MTs provided a space science laboratories, provided enough tables and chairs for 36 students, and include a set of equipment for the practice of science demonstrations and experiments learners. But there was still dioptimalkannya equipment available to the relevance also considering that administer teacher competence.

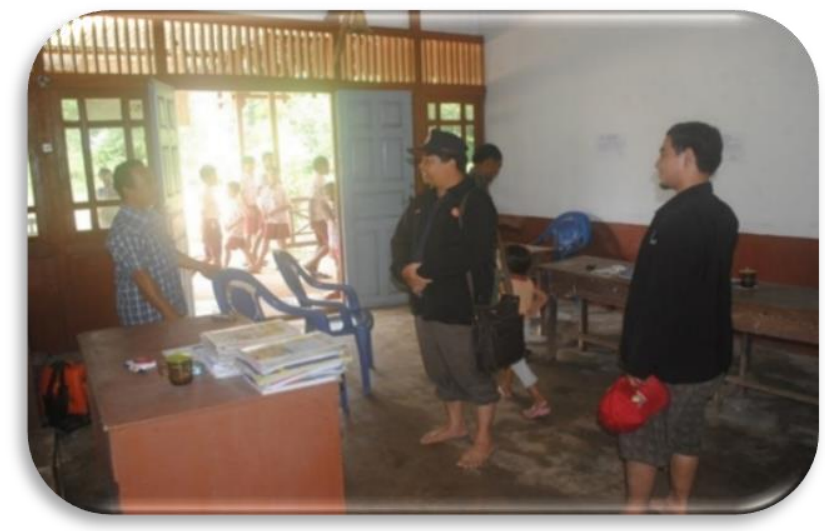

Fig. 4 Room teachers and school principals

In harmony with the matter in the aspect (IP-4) that provided a space teachers and principals (Figure 4) which is equipped with a table and chairs for every person teachers, principals and other education staff in SD/MTs and SMP/MTs. However, it is still in the category of pretty livable seen from a sense of comfort of the room.

Alternative policies that could be taken would be more appropriate if the first see the general picture ratio of students to study groups, it is necessary to look at the compatibility between the number rombel with the availability of classroom space so no rombel who do not have a classroom. Moreover, it can: 1) build new classrooms, 2) merge school and/or implementing the learning multigrade, 3) provision of additional means, 4) the grant of facilities, 5) renovation/remodeling of buildings classrooms for inadequate conditions, 6) providing support to schools to encourage preventive care classroom conditions that are still viable.

\section{B. Teachers and Education Personnel}

No matter how good the curriculum, means the preinfrastructure and management of the school, it is of course just expectations only if it is not supported by the competence of educators, terlbih again if the number or ratio of teachers to students is not appropriate, then of course it is very far from expectations associated with improving the quality of a school in an effort to improve the quality of their students. In line with this state that each SD / MI unavailable 1 (one) class teachers for each study group (IP-5).

With regard to the adequacy of classroom teachers, an alternative that can be taken: 1) transfer classroom teachers civil servants from the school / madrasah that excess teachers to schools / madrasah deficiency, 2) provide special incentives for teachers who are willing to be placed in the corners, 3) Conducting the recruitment of teachers new as needed, 4) Merger school for elementary school small shortage of teachers, and 5) Holding multigrade teaching to schools in special areas.

Furthermore, for each SMP / MTs only available subject teachers of Civics, English, Mathematics and Science, while others are not fulfilled for the teachers in each subject Religious Education, Indonesian, Social Sciences, Arts, PE, and ICT (IP-6). In any SD / MI and SMP / MTs provided two (2) teachers who meet the academic qualifications S1 or D-IV as much as $70 \%$ or more, but not available two (2) teachers 
who have a teaching certificate for the SD / MI, whereas in each SMP / MTs provided teachers with qualifications Akademiks-1 or D-IV and has been certified educator as much as 35\% more, especially for science subjects and English, but not for Mathematics and Bahasa Indonesia (IP-7, IP-8 and IP9).

With regard to the above data there are some things that can be used as an alternative to the policy as an effort to overcome the existing conditions, namely: 1) To increase the qualifications of teachers who have not S1/D-IV, 2) Doing the recruitment of new teachers who are already qualified S1/DIV, 3) Conducting the removal of teachers from schools with excess teacher S1/D-IV to schools that lack teachers S1/D-IV.

Besides that alternative in prioritizing the improvement of qualification of teachers who have not S1/D-IV would be more on target when priorities are arranged along with the fulfillment of the minimum requirements as contained in the Achievement Indicators-9 is a teacher of math, science, Bahasa Indonesia and Bahasa England must be qualified S1/D-IV and certified educators.

C. Qualifying School Principals and Supervisors

All heads of SD / MI has not qualified academic S-1 or D-IV and has a teaching certificate (IP-10), while for all the heads of SMP / MTs and all supervisors already qualified academic S-1 or D-IV, and has a teaching certificate (IP-11 and IP-12).

Associated with the condition, as an alternative policy that can be done to meet minimum service standards, especially for IP-10 can perform the way by: 1) providing scholarships to increase academic qualifications principals especially for the SD/MI, 2) Prioritize the certification of educators to principals, and 3) Conducting the promotion/appointment of new principal that already S1/D-IV that has been certified and meet other eligibility requirements. D. Curriculum and Supervisory Visits

In the aspect of curriculum development that district government has a plan and carry out activities to assist the education unit in developing the curriculum and innovative learning process. But they still lack the activities relating to curriculum development and program evaluation conducted for the implementation of development capable of generating an effective realization of the curriculum.

Visits education unit supervisors to do one every month and every visit was conducted for approximately 3 hours for supervision and coaching. Conditions such as these should be scaled back so that schools that were targeted by inspectors can be built faster in realizing the improvement of the quality of education in schools.

E. Linkages SPM Indicators of Basic Education with BOSP, Distribution Master and MBS

The following Table 2 description Minimum Service Standards relating to the three programs PERFORMANCE to assist local government to improve the quality of education, the Unit Cost of education (BOSP) so that schools obtain financial resources sufficient operational, Distribution Master (so that schools have adequate teachers) and Management based school (MBS) so that schools can manage its resources in a professional manner.

Table II

Indicators Linkages SPM with BOSP, Distribution Master, and MBS

\begin{tabular}{|c|c|c|}
\hline $\begin{array}{l}\text { Disribution Teachers } \\
\text { Indicators } 5 \text { - } 9\end{array}$ & MBS & BOSP \\
\hline 5. $\mathrm{Ea}$ & MI & -25 \\
\hline not & texto00 Ks & 7. Unit \\
\hline & & nt educ \\
\hline & Government & arriculum \\
\hline 6. There $\mathrm{S}$ & subjects & nce with ap \\
\hline available & Language, & regulations; \\
\hline teachers of Religion, & Science, Social Studi & 8. any teachers \\
\hline 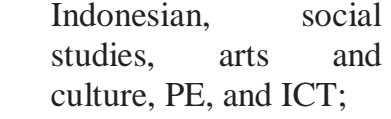 & $\begin{array}{l}\text { Civics, with a ratio of one set } \\
\text { for each learner; } \\
\text { 2. each SMP / MTs provides }\end{array}$ & $\begin{array}{l}\text { lesson plan (RPP } \\
\text { based on the sy } \\
\text { each subject diam }\end{array}$ \\
\hline $\begin{array}{l}\text { 7. any SD / MI provided } \\
\text { two (2) teachers who } \\
\text { meet the academic } \\
\text { qualifications S1 or D- }\end{array}$ & $\begin{array}{l}\text { textbooks that have been } \\
\text { defined for feasibility by the } \\
\text { Government covering all } \\
\text { subjects with a ratio of one }\end{array}$ & $\begin{array}{l}\text { acher to dev } \\
\text { ent an as } \\
m \text { to help } \\
\text { lity of learnes }\end{array}$ \\
\hline $\begin{array}{l}\text { IV but have } n \\
\text { teaching certifi }\end{array}$ & $\begin{array}{l}\text { set for each participant } \\
\text { learners; }\end{array}$ & $\begin{array}{l}\text { Principals } \\
\text { lessons and }\end{array}$ \\
\hline 8. Each & 3. $75 \%$ of $\mathrm{SD}$ & provide \\
\hline $\begin{array}{l}\text { provided teachers } \\
\text { academic qualific }\end{array}$ & $\begin{array}{l}\text { of teaching science and } \\
\text { materials consisting of a }\end{array}$ & $\begin{array}{l}\text { teachers twice in each } \\
\text { semester; }\end{array}$ \\
\hline of & human skeleton model, a & $y$ teacher \\
\hline $\begin{array}{l}\text { and half of them }(35 \% \\
\text { of total teachers) has } \\
\text { been } \\
\text { beertified }\end{array}$ & $\begin{array}{l}\text { model of the human body, a } \\
\text { globe (globe), examples of } \\
\text { optical equipment, science }\end{array}$ & $\begin{array}{l}\text { evaluation reports on } \\
\text { subjects as well as the } \\
\text { assessment of each learner }\end{array}$ \\
\hline
\end{tabular}




\begin{tabular}{|c|c|c|c|}
\hline $\begin{array}{l}\text { educators; } \\
\text { 9. There SMP / MTs are } \\
\text { not available teachers } \\
\text { with academic } \\
\text { qualification of S-1 or } \\
\text { D-IV and educator } \\
\text { certificate r for } \\
\text { Mathematics and } \\
\text { Indonesian. }\end{array}$ & & $\begin{array}{l}\text { kits for basic experiments } \\
\text { and poster IPA; } \\
\text { Only } 50 \% \text { of SD/MI which } \\
\text { has } 100 \text { titles enrichment and } \\
10 \text { reference books and each } \\
\text { SMP / MTs } 200 \text { items of } \\
\text { enrichment books and } 20 \\
\text { reference books; } \\
\text { Only 58.33\% of permanent } \\
\text { teachers work } 35 \text { hours per } \\
\text { week in unit-face education, } \\
\text { including activities in the } \\
\text { classroom, estab-learning } \\
\text { plan, implement-the learning, } \\
\text { assessing learning outcomes, } \\
\text { mem-guided and trained } \\
\text { learners, as well as carry out } \\
\text { additional tasks attached to } \\
\text { the implementation of the } \\
\text { main activities in accordance } \\
\text { with the workload of teachers } \\
66.66 \% \text { educational unit } \\
\text { organized a learning process } \\
\text { for } 34 \text { weeks per year with } \\
\text { the learning activities as } \\
\text { follows: } \\
\text { a. Class I - II : } 18 \\
\text { hours/week; } \\
\text { b. Class III : } 24 \text { hours/week; } \\
\text { c. Class IV - VI : } 27 \\
\text { hours/week; or } \\
\text { d. Class VII - IX : } 27 \\
\text { hours/week; }\end{array}$ & $\begin{array}{l}\text { to the principal at the end of } \\
\text { the semester in the form of } \\
\text { reports on the achievement } \\
\text { of learners. } \\
\text { 12. The head of the school or } \\
\text { madrasah submit a report of } \\
\text { a repeat end of the semester } \\
\text { (UAS) and Deuteronomy } \\
\text { Increase Class (UKK) and } \\
\text { final test (US/UN) to the } \\
\text { parents of learners and } \\
\text { deliver the recap to the } \\
\text { District Education Office/ } \\
\text { City or the Office of } \\
\text { Religious Affairs in the } \\
\text { district / cities at the end of } \\
\text { each semester. } \\
\text { 13. Each educational unit has } \\
\text { sought to apply the } \\
\text { principles of school-based } \\
\text { management (SBM). }\end{array}$ \\
\hline
\end{tabular}

The results of an analysis of 14 indicators of SPM for the Department of Education and 13 indicators SPM for Education Unit show that has not been fully met as stipulated in the rules Permendiknas (figure 5). That is, there are still gaps in the Territory of the SPM Cabdikpora and Education Unit in the District of Entikong.

Thus required no further activity in order to meet a variety of SPM to overcome the existing gaps. Based on the achievements of the existing SPM needs to be further restructuring efforts in order to meet the SPM as well as the maintenance of the achievements of the fulfillment of SPM has been achieved.

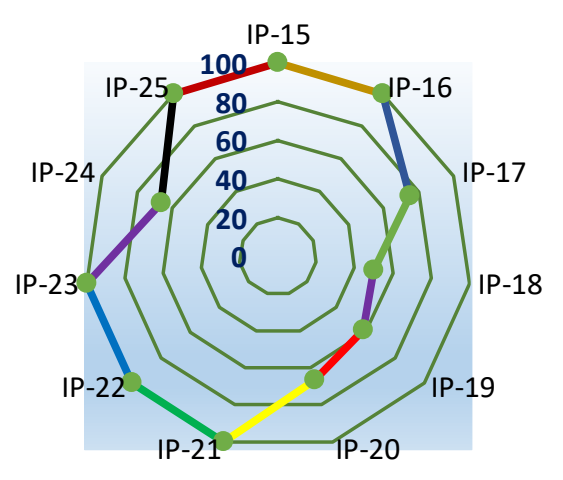

Fig.5 Indicators of achievement

In this framework, Cabdikpora Entikong and Education Unit require both funding and moral support of all internal elements, committees, supervisors, government and productive synergy between the District Education Office, the Office of Education Districts, as well as the Education Unit. 


\section{CONCLUSION}

Based on the results of research in general standard of basic education services in District Entikong Sanggau when referring to Permendiknas 15 Year 2010 on Minimum Service Standards for Basic Education in general is still far from the expected. The conclusions obtained based on the indicators used to measure the minimum service standards are:

1. Availability of educational unit within reasonable walking distance is a maximum of $3 \mathrm{~km}$ for SD/MI and $6 \mathrm{~km} \mathrm{road} /$ water for SMP/MTs of a group of permanent settlements in remote areas.

2. The number of students in each group learning for $\mathrm{SD} / \mathrm{MI}$ does not exceed 32 people, while SMP/MTs exceed 36 people.

3. Each group learn SD/MI and SMP/MTs not available 1 (one) classrooms and there are not furnished with a table and chairs.

4. Each SMP/MTs provided a space science laboratories, provided enough tables and chairs for 36 students, and include a set of equipment for the practice of science demonstrations and experiments learners.

5. There is one space teachers and principals are equipped with tables and chairs for all teachers, principals and other education staff in SD/MTs and SMP/MTs.

6. Each SD/MI unavailable 1 (one) class teachers for each study group.

7. Each SMP/MTs only available subject teachers of Civics, English, Mathematics and Science, while others are not fulfilled for the teachers in each subject Religious Education, Indonesian, Social Sciences, Arts, Culture, and ICT.

8. Each SD/MI and SMP/MTs provided two (2) teachers who meet the academic qualifications S1 or D-IV as much as $70 \%$ or more, but do not have the teaching certificate for the SD/MI. And each SMP/MTs provided teachers with academic qualification of S-1 or D-IV and has been certified educator as much as $35 \%$ more, especially for science subjects and English, but not for Mathematics and Bahasa Indonesia.

9. Head of SD/MI has not qualified academic S-1 or DIV and have a teaching certificate, while for all the heads of SMP/MTs and all supervisors already qualified academic S-1 or D-IV, and has a teaching certificate.

10. Visits education unit supervisors to do once a month for approximately 3 hours/visit, and the district government has a plan and carry out activities to assist in developing the education unit curriculum and innovative learning process, but has not been implemented optimally.

11. any SD / MI provides textbooks that have been defined for feasibility by the Government includes subjects Indonesian Language, Mathematics, Science,
Social Studies and Civics, with a ratio of one set for each learner.

12. Each SMP/MTs provides textbooks that have been defined for feasibility by the Government covering all subjects with a ratio of one set for each participant students.

13. $75 \%$ SD / MI provides a set of teaching science and materials consisting of a human skeleton model, a model of the human body, a globe (globe), examples of optical equipment, science kits for basic experiments and poster IPA;

14. Only 50\% of SD / MI which has 100 titles enrichment and 10 reference books and each SMP / MTs 200 items of enrichment books and 20 reference books;

15. Only $58.33 \%$ of permanent teachers work 35 hours per week in unit-face education, including activities in the classroom, estab-learning plan, implement-the learning, assessing learning outcomes, mem-guided and trained learners, as well as carry out the task additional attached to the implementation of the main activities in accordance with the workload of teachers;

16. $66.66 \%$ educational unit organized a learning process for 34 weeks per year with the following learning activities:

a.Class I - II : 18 hours/week;

b.Class III : 24 hours/week;

c.Class IV - VI : 27 hours/week; and

d.Class VII - IX : 27 hours/week;

17. Unit of education implement education unit level curriculum in accordance with applicable regulations.

18. Each teacher implement the lesson plan which is based on the syllabus for each subject diampunya and develop and implement an assessment program to help improve the ability of learners.

19.66.66\% Principals supervising lessons and provide feedback to teachers twice each semester.

20. Every teacher submit evaluation reports on subjects as well as the assessment of each learner to the principal at the end of the semester in the form of reports on the achievement of learners.

Madrasah principal or submit a report of a repeat end of the semester and Deuteronomy Increase Class and final test (US/UN) to the parents of learners and deliver the recap to the District Education Office/City at the end of each semester.

\section{REFERENCES}

Arikunto, Suharsimi. 2010. Prosedur Penelitian: Suatu Pendekatan Praktik. Jakarta: Rineka Cipta.

Azwar, Saifuddin. 2005. Metode Penelitian. Yogyakarta: Pustaka Pelajar.

Permendikbud Nomor 23 Tahun 2013 Tentang Standar Pelayanan Minimal Pendidikan Dasar di Kabupaten/Kota.

Undang-Undang Nomor 25 Tahun 2009 tentang Pelayanan Publik. 
Journal of Education, Teaching and Learning

Volume 3 Number 1 March 2018. Page 104-112

p-ISSN: 2477-5924 e-ISSN: 2477-8478

USAID. 2014. Tata Kelola Penerapan Standar Pelayanan Minimal Bidang Pendidikan Dasar untuk Kabupaten/Kota. Jakarta: Program Kinerja (Public Service 
Journal of Education, Teaching and Learning

Volume 3 Number 1 March 2018. Page 104-112

p-ISSN: 2477-5924 e-ISSN: 2477-8478 